\title{
HUBUNGAN ANTARA TINGKAT KEPARAHAN PMS DENGAN TINGKAT KECEMASAN DAN KUALITAS TIDUR PADA REMAJA PUTRI
}

\author{
Henny Dwi Susanti, Reni Ilmiasih, Ari Arvianti \\ Program Studi IImu Keperawatan, Fakultas IImu Kesehatan, Universitas Muhammadiyah Malang \\ Jl. Bendungan Sutami 188A Malang JawaTimur \\ e-mail : hanisusanti@yahoo.com
}

\begin{abstract}
Pre Menstrual Syndrome (PMS) is a collection of physical symptoms, psychological, and emotions associated with the woman's menstrual cycle and consistently occur during the luteal phase of the menstrual cycle due to hormonal changes associated with the current cycle of ovulation (release of eggs from the ovary) and menstruation. Some of the complaints were felt during PMS, such as headache, back pain, breast pain, sleep disorders, and more than a few complaints can cause anxiety in women with PMS. This research was conducted observational analytic with cross sectional method. levels of anxiety and sleep quality in adolescent girls (as dependent variable). The sample used in this research were 30 students. Total sampling is a sampling technique in which the number of samples is equal to the population. there is a significant correlation between the severity of PMS with the level of anxiety. A positive correlation coefficient indicates that the relationship between the severity of PMS with anxiety levels. The more severe or severe PMS level, the level of anxiety is also heavier. Conversely, the mild severity of PMS, the anxiety level is also lighter. There is a significant correlation between the severity of PMS with the quality of sleep.
\end{abstract}

Keywords : severity PMS, level of anxiety, quality sleep, adult

\begin{abstract}
Abstrak : Pre Menstrual Syndrome (PMS) merupakan kumpulan gejala fisik, psikologis, dan emosi yang terkait dengan siklus menstruasi wanita dan secara konsisten terjadi selama tahap luteal dari siklus menstruasi akibat perubahan hormonal yang berhubungan dengan siklus saat ovulasi (pelepasan sel telur dari ovarium) dan menstruasi. Beberapa keluhan yang dirasakan saat PMS yaitu sakit kepala, sakit punggung, nyeri pada payudara, gangguan tidur, dan lain-lain.Akibat dari beberapa keluhan yang dirasakantersebut dapat menimbulkan kecemasan pada wanita yang mengalami PMS. Penelitian ini dilakukan secara observasional analitik dengan metode pendekatan cross sectional. tingkat kecemasan dan kualitas tidur pada remaja putri (sebagai variabel dependen). Sampel yang digunakan dalam penelitian ini berjumlah 30 siswi. Total sampling adalah teknik pengambilan sampel dimana jumlah sampel sama dengan populasi. terdapat hubungan yang signifikan antara tingkat keparahan PMS dengan tingkat kecemasan. Koefisien korelasi yang positif menunjukkan bahwa hubungan antara tingkat keparahan PMS dengan tingkat kecemasan. Semakin parah atau berat tingkat PMS, maka tingkat kecemasan juga semakin berat. Sebaliknya, semakin ringan tingkat keparahan PMS, maka tingkat kecemasan juga semakin ringan. Terdapat hubungan yang signifikan antara tingkat keparahan PMS dengan kualitas tidur.
\end{abstract}

Kata kunci : tingkat keparahan,PMS, tingkat kecemasan, kualitas tidur, remaja.

\section{PENDAHULUAN}

Masa remaja atau masa
aldolescence adalah suatu fase per-
kembangan yang dinamis dalam kehidup-
an seorang individu. Masa remaja terjadi
lebih dini pada remaja putri dibanding
remaja putra, dan kemungkinan terjadinya
perbedaan ini dikarenakan remaja putri
lebih cepat matang dalam hal psikologikal
dan emosionalnya (Liali \& Dewi,2014).
Pada masa ini, remaja putri akan meng-
alami perubahan yang sangat penting,
yaitu perubahan fisik dan psikologis.
Perubahan fisik yang dimaksud adalah

proses kematangan yang terjadi pada organ reproduksi remaja putri yang ditandai dengan peristiwa menstruasi, yaitu peristiwa pengeluaran darah dari dalam rahim bila sel telur tidak dibuahi (Aloysiusdkk, 2007). Menstruasi atau pendarahan periodik normal uterus merupakan proses katabolisme yang terjadi akibat adanya pengaruh dari hormon hipofisis dan ovarius, seperti hormon esterogen dan progesteron. Umumnya menstruasi akan terjadi secara normal setiap bulan (Ratikasari, 2015). 
Biasanya 7-10 hari sebelum terjadi menstruasi, wanita akan mengalami beberapa gejala perubahan tertentu dari segi fisik (nyeri payudara, sakit kepala, jerawat, nyeri panggul bahkan edema) maupun emosional (perubahan mood, penurunan fungsi sosial, penurunan konsentrasi bahkan depresi dan kecemasan) yang akan mereda ketika siklus menstruasi dimulai. Namun pada beberapa wanita juga dapat terjadi gejala yang terus berkelanjutan hingga $24-48$ jam pertama siklus menstruasi dan akan mereda selama beberapa hari kedepan. Gejala - gejala tersebut dikenal dengan Pre Menstrual Syndrome (Ratikasari, 2015).

Pre Menstrual Syndrome (PMS) merupakan kumpulan gejala fisik, psikologis, dan emosi yang terkait dengan siklus menstruasi wanita dan secara konsisten terjadi selama tahap luteal dari siklus menstruasi akibat perubahan hormonal yang berhubungan dengan siklus saat ovulasi (pelepasan sel telur dari ovarium) dan menstruasi (Laili \& Dewi, 2014). Penyebab dari adanya PMS ini diperkirakan karena adanya efek progesteron dalam neurotransmitter seperti pada seorotonin, opioid, katekolamin dan GABA (Gamma Aminobutyric Acid), peningkatan sensitifitas akibat peningkatan level prolaktanin, resistensi insulin dan defisiensi nutrisi (Kalium, Magnesium, dan B6) (Firoozi et.al., 2012). Sepanjang periode menstruasi awal, gejala yang sering dialami remaja putri adalah sakit kepala, sakit punggung, kejang dan sakit perut yang terkadang dapat diikuti dengan gejala pingsan, mual, muntah, gangguan kulit, pembengkakan tungkai kaki dan pergelangan kaki. Akibat timbul rasa lelah, tertekan, cemas, dan mudah marah (Al-Mighwar, 2007). Berbagai gejala emosional yang paling umum dialami wanita saat PMS salah satunya timbul suatu kecemasan ketika menghadapi PMS (Laili \& Dewi, 2014).

Kecemasan sebagai salah satu gejala utama dan gangguan tidur seperti insomnia atau hiperinsomnia merupakan gejala penyerta dari PMS (Kathleen et.al.,2010). Kecemasan adalah salah satu keadaan yang ditandai dengan perasaan ketakutan yang disertai dengan tanda somatik yaitu terjadinya hiperaktivitas sistem saraf otonom. Kecemasan merupakan gejala yang tidak spesifik yang sering di temukan dan sering kali merupakan suatu emosi yang normal. Remaja yang mengalami pubertas akan lebih cepat murung, khawatir, cemas, marah, dan menangis hanya karena hasutan yang sangat kecil ( $\mathrm{Al}$ - Mighwar, 2007). Pada awal siklus menstruasi, remaja akan lebih rentan untuk mengalami PMS. Hal ini dapat diperkuat dengan adanya penurunan serotonin saat fase luteal yang dapat menstimulasi gangguan mood (Firoozi et al., 2012). Selain itu, tingkat gangguan mood akan cenderung meningkat dengan adanya perubahan hormon pada remaja (Anggrajani \& Muhdi, 2011).

Penyebab pasti munculnya kecemasan dalam menghadapi PMS diantaranya adalah faktor hormonal pada tubuh wanita, yaitu ketidakseimbangan antara hormon estrogen dan progesterone. Beberapa keluhan yang dirasakan saat PMS yaitu sakit kepala, sakit punggung, nyeri pada payudara, gangguan tidur, dan lain-lain. Akibat dari beberapa keluhan yang dirasakan tersebut dapat menimbulkan kecemasan pada wanita yang mengalami PMS. Apabila kecemasan tidak diatasi segera akan dapat menimbulkan berbagai respon kecemasan, antara lain gelisah, keringat dingin, takut, dan berbagai gangguan kesehatan seperti, diare, sering berkemih, mual muntah dan lain- lain. Kecemaasan menyangkut respon parasimpatis yang meningkatkan aktifitas sistem pencernaan (Laili \& Dewi, 2014).

Wanita dengan PMS di Australia dilaporkan sulit mengalami dan memulai tidur, gagal dalam bangun tidur diwaktu yang ditentukan dan peningkatan ketidak nyamanan saat tidur. Efisiensi tidur pada wanita PMS sebenarnya hampir sama disetiap fasenya. Namun, kualitas tidur dapat mengalami gangguan jika wanita tersebut mengalami depresi atau kecemasan (Baker et. al., 2007). Tidur merupakan suatu stase aktif, penting untuk fisik mental dan emosional agar dalam kondisi yang baik dan penting pula untuk mengoptimalkan fungsi otak dan tubuh secara umum. Masalah - masalah 
dalam proses tidur sangat umum dan berpengaruh pada 20\% remaja (Roth, 2008). Survey data yang di indentifikasi terkait gangguan pada kualitas tidur, seperti sulit tidur, fatigue, letargi, dan insomnia. Namun masih sangat sedikit penelitian yang mengidentifikasikan terkait gangguan tidur pada wanita yang mengalami PMS (Bakeret.al.,2007).

Menurut penelitian dalam survey di Amerika Serikat menunjukkan sekitar $40 \%$ wanita berusia 14-50 tahun, mengalami PMS dan 50\% PMS dialami wanita dengan sosial-ekonomi menengah yang datang ke Klinik Ginekologi. Data dari jurnal Archieves of Internal Medicine, 90\% perempuan mengalami PMS sebelum menstruasi dan studi yang dilakukan terhadap 3000 wanita, sekitar 90\% perempuan mengalami satu atau lebih tanda atau gejala PMS. Berdasarkan data dari Divisi Imunoendokrinologi Reproduksi Departemen Obstetri dan Ginekologi Fakultas Kedokteran Universitas Indonesia RSCM.

PMS merupakan kondisi medis umum yang memengaruhi hubungan wanita, aktivitas sosial, produktivitas kerja dan kualitas hidup. Berbagai gejala emosional yang paling umum dialami wanita saat pra-haid meliputi perasaan mudah tersinggung sebanyak $48 \%$ dan timbul suatu kecemasan ketika menghadapi PMS, kurang berenergi atau lemas $45 \%$ dan mudah marah $39 \%$. Gejala fisik yang paling umum dialami wanita meliputi kram ataunyeri perut $51 \%$, nyeri sendi, otot atau punggung $49 \%$, nyeri pada payudara $46 \%$ dan perut kembung $43 \%$ (Wahyuni, 2014).

Pada tahun 2011, Mahin et, al melakukan penelitian tentang PMS di Iran, ditemukan sebanyak 98,2\% mahasiswi yang berusia 18-27 tahun mengalami gejala sindrom premenstruasi. Gejala yang dirasakan berupa gejala fisik dan psikologis yang memengaruhi aktivitas sehari-hari, penurunan minat belajar dan fungsi sosial terganggu. Adapun penelitian yang dilakukan oleh American College of Obstetricians and Gynecologists (ACOG) pada tahun 2011 di Srilanka, diperoleh hasil bahwa remaja yang mengalami sindrom premenstruasi sekitar $65,7 \%$. Gejala yang sering muncul adalah perasaan sedih dan tidak berpengharapan sebesar 29,6\%. (Singal, 2013)

Berdasarkan data yang diperoleh dari Departemen Kesehatan tahun 2009 tentang prevalansi sindrom premenstruasi di Indonesia, diperoleh hasil sebanyak $40 \%$ wanita Indonesia mengalami sindrom premenstruasi dan sebanyak $2-10 \%$ mengalami gejala berat. Berdasarkan penelitian yang dilakukan oleh Puspitorini pada mahasiswi Akademi Kebidanan Pemerintah Kabupaten Kudus pada tahun 2007, dari 259 subyek penelitian, terdapat 109 mahasiswi atau 42,9\% yang mengalami PMS. Hal ini mengakibatkan penurunan konsentrasi belajar, terganggunya komunikasi dengan teman di kampus juga terjadi penurunan produktivitas belajar di asrama dan peningkatan absensi (Singal, 2013).

Hasil studi pendahuluan pada remaja putri di SMP Muhammadiyah 4 Malang didapatkan 4 dari 8 atau jika dipersentasikan sebesar $50 \%$ remaja putri menyatakan bahwa dirinya sering mengalami ganguan tidur, perubahan fisik, emosional, dan kecemasan yang tiba-tiba dan tanpa sebab saat akan menstruasi. Bahkan, perubahan tersebut mengakibatkan mereka harus berdiam di Unit Kesehatan Sekolah dan tidak mengikuti pelajaran di sekolah mereka. Oleh karena itu peneliti tertarik untuk melakukan penelitian terkait hubungan antara tingkat keparahan PMS dengan tingkat kecemasan dan kualitas tidur pada remaja putri di SMP Muhammadiyah 4 Malang.

\section{METODE PENELITIAN}

Penelitian ini dilakukan secara observasional analitik dengan metode pendekatan cross sectional. Metode pendekatan cross sectional merupakan penelitian dengan melakukan pengukuran atau pengalamatan pada saat bersamaan (sekali waktu) antara faktor resiko atau paparan dengan penyakit (Hidayat, 2007). Pada studi ini diperoleh hubungan tingkat keparahan PMS (sebagai variabel independen) dengan tingkat kecemasan dan kualitas tidur pada remaja putri (sebagai variabel dependen). Sampel yang digunakan dalam penelitian ini berjumlah 30 siswi. Total sampling adalah 
teknik pengambilan sampel dimana jumlah sampel sama dengan populasi. Instrumen Penelitian ini menggunakan kueisioner yang dibagi menjadi 4 bagian, bagian 1 merupakan data demografi, bagian 2 merupakan kuesioner PMS, bagian 3 merupakan kesioner tingkat kecemasan / ansietas dan bagian 4 merupakan kuesioner kualitas tidur. Analisis data yang dilakukan untuk menilai hubungan antara tingkat keparahan PMS dengan tingkat kecemasan dan kualitas tidur pada remaja putri digunakan perhitungan statistik. Teknik analisis data dengan menggunakan korelasi Rank Spearman, $\alpha=$ 0,05 dengan tingkat kepercayaan 95\%. Apabila $\alpha=<0,05$ artinya $\mathrm{H} 1$ diterima yaitu ada hubungan tingkat keparahan PMS dengan tingkat kecemasan dan kualitas tidur pada remaja putri. Apabila $\alpha=>0,05$ HO ditolak yaitu tidak ada hubungan tingkat keparahan PMS dengan tingkat kecemasan dan kualitas tidur pada remaja putri.

\section{HASIL PENELITIAN}

Berdasarkan hasil pengujian, didapatkan tabel frekuensi tingkat keparahan PMS sebagai berikut: Distribusi Frekuensi Responden Berdasarkan Tabel 1. Hasil Pengujian Hubungan Tingkat Keparahan PMS dengan Tingkat Kecemasan

\begin{tabular}{|c|c|c|c|c|c|}
\hline \multirow{2}{*}{ PMS } & \multicolumn{3}{|c|}{ Kecemasan } & \multirow{2}{*}{$\mathrm{R}$} & \multirow[b]{2}{*}{$p$-value } \\
\hline & Tidak Ada & Ringan & Sedang & & \\
\hline $\begin{array}{l}\text { Ringan } \\
\text { Sedang }\end{array}$ & $\begin{array}{c}3 \% \\
-\end{array}$ & $\begin{array}{c}30 \% \\
-\end{array}$ & $\begin{array}{l}30 \% \\
37 \%\end{array}$ & 0,534 & 0,002 \\
\hline Total & $3 \%$ & $30 \%$ & $68 \%$ & & \\
\hline
\end{tabular}

Berdasarkan hasil pengujian hubungan antara tingkat keparahan PMS dengan tingkat kecemasan didapatkan koefisien korelasi sebesar 0,534 p-value sebesar 0,002 artinya terdapat hubungan yang signifikan antara tingkat keparahan PMS dengan tingkat kecemasan. Koefisien
Tingkat Keparahan PMS didapatkan bahwa dari 30 siswi di SMP Muhammadiyah 4 Malang, sebagian besar responden mengalami PMS dengan katagori ringan $(n=19,63 \%)$, sedangkan minoritas responden mengalami PMS dengan katagori sedang $(n=11,37 \%)$.

Berdasarkan hasil pengujian, didapatkan tabel frekuensi tingkat kecemasan yaitu dari 30 siswi di SMP Muhammadiyah 4 Malang sebagaian besar mengalami kecemasan dengan katagori sedang $(n=20$, $67 \%$ ), dan hanya satu responden yang tidak mengalami kecemasan (3\%).

Distribusi Frekuensi Responden Berdasarkan Kualitas Tidur didapatkan bahwa 30 siswi sebagian besar memiliki kualitas tidur dengan katagori buruk19 siswi $(63 \%)$, dan sisanya memiliki kualitas tidur dengan katagori baik $(n=11,39 \%)$.

Pengujian bivariat menggunakan analisis korelasi Rank Spearman dilakukan untuk mengetahui hubungan antara tingkat keparahan PMS dengan tingkat kecemasan pada 30siswi di SMP Muhammadiyah 4 Malang. Berikut hasil pengujian dengan menggunakan analisis korelasi Rank Spearman :

Tabel 2. Hasil Pengujian Hubungan Keparahan PMS dengan Kualitas Tidur

\begin{tabular}{|c|c|c|c|c|}
\hline \multirow{2}{*}{ PMS } & \multicolumn{2}{|c|}{ Kualitas Tidur } & \multirow{2}{*}{$\mathrm{R}$} & \multirow{2}{*}{$p$-value } \\
\hline & Baik & Buruk & & \\
\hline $\begin{array}{l}\text { Ringan } \\
\text { Sedang }\end{array}$ & $\begin{array}{c}10(33 \%) \\
1(3 \%)\end{array}$ & $\begin{array}{c}9(30 \%) \\
10(33 \%)\end{array}$ & 0,435 & 0,016 \\
\hline Total & $11(36 \%)$ & $19(64 \%)$ & & \\
\hline
\end{tabular}




\section{PEMBAHASAN}

Pada hasil penelitian ini didapatkan nilai skor tertinggi kuesioner PMS yang dialami responden yaitu meliputi gejala fisik dan psikis. Gejala fisik yang sering dialami responden yaitu nyeri atau perasaan tidak nyaman di bagian perut, sedangkan gejala psikis yang sering dialami adalah perasaan mudah marah. Hal ini diperkuat menurut penelitian Rusfiana dan Rodiana (2016) yang menyatakan bahwa banyak kondisi atau faktor yang berperan dalam terjadinya PMS pada remaja. Rendahnya kadar progesteron diduga menjadi penyebab utama terjadinya PMS. Faktor yang terkait dengan PMS adalah kenaikan perbandingan estrogen terhadap progesteron, tepat sebelum fase menstruasi terjadi. Beberapa penelitian membuktikan bahwa peningkatan rasio ini terkait dengan penurunan kadar endofin otak. Kadar endorfin otak diketahui berpengaruh meningkatkan perasaan senang. Pertambahan kadar estrogen juga berdampak pada pemekatan konsentrasi aldosteron, hormon yang dapat meretensi air dan natrium. Perubahan ini menyebabkan perubahan endomorfin, prolaktin, dan aldosteron yang dapat memperburuk gejala fisik dan psikis PMS (Schuleet.al., 2014)

Pada penelitian ini didapatkan bahwa rata - rata usia responden saat ini adalah \pm 13 tahun, dimana usia 13 tahun termasuk usia remaja. Hal ini juga sesuai dengan pendapat Nasir dan Muhith (2011), yang menyatakan bahwa ketika memasuki usia remaja, maka akan mengalami menstruasi dan perubahan perubahan kelamin sekunder. Dimana pada usia remaja atau pubertas, wanita akan mengalami perubahan level hormon, sehingga akan mulai memicu terjadinya PMS.

Berdasarkan hasil penelitian yang dilakukan pada 30 siswi di SMP Muhammadiyah 4 Malang sebagian besar mengalami kecemasan dengan katagori sedang dan hanya satu responden yang tidak mengalami kecemasan. Hal tersebut dapat diartikan bahwa paling banyak remaja putri mengalami kecemasan dengan kategori sedang. Hasil penelitian ini juga didapatkan bahwa gejala yang sering dialami responden bervariasi mulai dari yang bersifat fisik dan psikis. Adapun gejala yang paling parah yang dialami responden adalah perasaan depresi (murung) seperti hilangnya minat, berkurangnya kesenangan atau hobi, sedih, bangun dini hari, perasaan berubah - ubah sepanjang hari. Penyebab pasti munculnya kecemasan dalam menghadapi PMS diantaranya adalah faktor hormonal pada tubuh wanita, yaitu ketidakseimbangan antara hormon estrogen dan progesteron. Beberapa keluhan yang dirasakan saat PMS yaitu sakit kepala, sakit punggung, nyeri pada payudara, gangguan tidur, dan lain-lain. Akibat dari beberapa keluhan yang dirasakan tersebut dapat menimbulkan kecemasan pada wanita yang mengalami PMS (Indusekharet.al., 2007).

Apabila kecemasan tidak diatasi segera akan dapat menimbulkan berbagai respon kecemasan, antara lain gelisah, keringat dingin, takut, dan berbagai gangguan kesehatan seperti, diare, sering berkemih, mual muntah dan lain - lain, karena kecemaasan menyangkut respon parasimpatis yang meningkatkan aktifitas system pencernaan (Ichikawa, et.al,2008). Ketika wanita mengalami fase pre menstrual, maka sudah lebih mempengaruhi progesteron yang terdapat di neuro transmitter seperti serotonin, katekolamin dan GABA. Peningkatan level Prolaktin atau peningkatan sensitivitas terhadap efek prolaktin, sensitivitas untuk hormon endogen, dan resistensi insulin dapat mempengaruhi rangsangan pada neurotransmitter akibat adanya efek progesterone (Rocha, et., al., 2011). Efek progesterone dan esterogen tersebut dapat menurunkan serotonin, beta endorphin dan GABA selamafase luteal, sehingga dapat memprofokasi timbulnya gejala negative mood dan reaksi emosional yang berkebalikan. Oleh karena itu wanita akan lebih sering mengalami stress pada faseini (Firoozi, et., al., 2012). Hal ini dapat diperkuat pula dengan pernyataan bahwa PMS dapat mempengaruhi penurunan kadar monoamine oksidase pada otak yang dihubungkan dengan terjadinya depresi dan penurunan serotonin sehingga menimbulkan perubahan mood (Presti \& Puspitosari, 2010). 
Berdasarkan hasil analisis secara deskriptif ditinjau dengan hasil distribusi frekuensi, ditunjukkan bahwa dari 30 siswi di SMP Muhammadiyah 4 Malang, sebagian besar mengalami kualitas tidur burukdan beberapadiantaralainya memiliki kualitas tidur dengan katagori baik. Kualitas tidur pada remaja yang berbeda beda umumnya di sebabkan karena perbedaan aktivitas yang berbeda untuk setiap orang. Usia remaja $12-18$ tahun umumnya normal waktu tidur adalah 8 10 jam per malam. Hasil penelitian dari 30 remaja putri di SMP Muhammadiyah 4 Malang, rata - rata lama waktu tidur 5 - 6 jam per malam. Waktu yang digunakan memulai tidur pukul 23:00 dan bangun bukul 4 - 5 pagi. Menurut hasil penelitian, jika dilihat dari segi waktu, gangguan tidur dan kebiasaan tidur sebagian besar remaja telah menunjukkan kualitas tidur yang buruk.

Pada penelitian ini juga didapatkan hasil bahwa dari ke tujuh komponen kualitas tidur yang sangat parah yang dirasakan responden yaitu komponen gangguan tidur yang berisi terbangun di malam hari atau terlalu pagi, terbangun karena ingin ke kamar mandi, tidak bisa bernafas dengan nyaman, batuk tersedak atau mendengkur terlalu keras, merasa terlalu dingin dan atau panas, mendapatkan mimpi buruk, merasa nyeri perut akibat PMS dan menyebutkan gangguan lainnya jika ada.

Gangguan kualitas tidur pada fase luteal ini disebabkan karena adanya peningkatan metabolisime otak dan kortikal. Padahal seharusnya saat seseorang tidur aktivitas metabolisme menurun, sehingga tidur menjadi lebih nyaman. Namun jika aktivitas metabolis meningkat, maka seseorang akan mengalami gangguan pada onset REM dan terjadinya peningatan saraf otonom. Peningkatan saraf otonom ini juga berhubungan dengan gangguan tidur seperti insomnia atau hyperinsomnia. Selain itu, kualitas tidur juga dipengaruhi oleh perubahan mental yang menurun dan terlihat jelas pada remaja (Baker, et., al.,2007). Berdasarkan teori di atas di perkuat dengan hasil penelitian sebelumnya bahwa ansietas atau kecemasan merupakan gejala mayor yang sering muncul.
Ansietas atau kecemasan yang terjadi saat fase luteal ini dikarenakan adanya peningkatan level prolaktin yang dapat mempengaruhi rangsangan pada neurotransmitter yang dapat memicu kecemasan. Penurunan serotonin, beta endorphin dan kadar monoamine oksida sedalam otak juga merupakan kondisi salah satu pemicu munculnya ansietas pada wanita yang berada dalam kondisi PMS. Sedangkan hyper insomnia atau insomnia dapat menjadi salah satu indikasi kualitas tidur seseorang (Baker et., al. 2007).

Menurut sebuah penelitian,didapatkan kualitas tidur dapat diasosiasikan dengan status mental yang rendah (dapat berupa gangguan mood, depresi maupun ansietas/kecemasan). Gangguan kualitas tidur tersebut lebih sering terjadi dalam masa remaja yang mengalami PMS. Hal ini terlihat dari hasil hubungan dengan perubahan tidur pada 500 remaja putri SMP di Jepang yang mengalami PMS (Kaneita et al,2009).

Berdasarkan hasil pengujian hubungan antara tingkat kepatahan PMS dengan tingkat kecemasan menggunakan korelasi Rank Spearman, ditunjukkan bahwa terdapat hubungan yang positif $(r=$ 0,534 dan $p=0,002$ ) antara tingkat keparahan PMS dan tingkat kecemasan. Semakin berat tingkat keparahan PMS maka semakin berat tingkat kecemasannya. Sebaliknya, semakin ringan tingkat keparahan PMS, maka tingkat kecemasan juga semakin ringan.

Bila terjadi kecemasan maka tubuh akan bereaksi secara otomatis berupa perangsangan hormon \& neurotransmitter. Terjadi peningkatan secara cepat sekresi adrenocorticotropic hormone (ACTH) yang akan merangsang kelenjar adrenal untuk menghasilkan kortisol. Keadaan ini dianggap sebagai akibat dari naiknya aktivitas dalam sistem limbik, khususnya dalam region amigdala dan hipokampus yang kemudian menjalarkan sinyal ke bagian posterior medial hipotalamus. Kortisol ini akan menginhibisi pelepasan LH(Luteinizing hormone) dan FSH (Follicle Stimulating Hormone) oleh kelenjar pituitari, hormon estrogen dan progesteron oleh ovarium, dan menginduksi resistensi hormon estrogen di organ target. Hal ini 
yang menyebabkan ketidakseimbangan hormon estrogen progesteron selama fase luteal (Kia, et.al., 2015).

Serotonin di dalam system saraf pusat juga mencetuskan kondisi marah, gejala depresi dan menginginkan makanan yang spesifik. Penyebab seperti yang telah disebutkan tersebut lebih rentan terjadi pada remaja. Hal ini dikarenakan saat remaja, organ belum matang sempurna, sehingga kemungkinan untuk terjadi ketidakseimbangan lebih besar. Hal ini disesuaikan dengan tahap perkembangan remaja awal, dimana akan terjadi pematangan secara primer (PerezLopez et.,al 2009).

Teori diatas sesuai dengan penelitian Firooziet.,al (2012) yang mengatakan bahwa terdapat gejala gejala psikiatrik seperti kecemasan, depresi, agresi, dan gangguan interpersonal. Dimana ketika PMS yang dirasakan semakin berat atau semakin parah, maka kecemasan yang dirasakan akan meningkat pula. Keadaaan tersebut dikarenakan adanya ketidakseimbangan hormon saat remaja memasuki fase luteal. Berdasarkan hasil pengujian hubungan antara tingkat kepatahan PMS dengan kualitas tidur, ditunjukkan bahwa terdpat hubungan yang negatif $(r=-0,435$ dan $p$ $0,016)$ antara tingkat keparahan PMS denagn kualitas tidur. Semakin parah atau berat tingkat keparahan PMS, maka semakin buruk kualitas tidur. Sebaliknya, semakin ringan tingkat keparahan PMS, maka kualitas tidur juga semakin baik. Hasil penelitian menunjukkan ada-nya hubungan antara tingkat keparahan PMS dengan kualitas tidur. Sebanyak $63 \%$ kualitas tidur responden dalam ambang buruk, sehingga dapat disimpulkan bahwa responden dalam kondisi kecemasan, mereka tidak bisa mengukur waktu tidur seperti saat tidak sedang mengalami PMS.

Menurut Gracia, dkk (2011), faktor yang mempengaruhi suatu proses tidur normal. Tidur dipengaruhi oleh hormon -

\section{DAFTAR PUSTAKA}

AlMighwar,M.(2007). Psikologi Remaja (Petunjuk Bagi Guru dan Orang Tua). Bandung : Pustaka Setia. hormon di dalam tubuh, antara lain serotonin , L-triptofan, norepinefrine, dan asetilkolin otak. PMS dapat menyebabkan gangguan tidur karena pengaruh serotonin. Serotonin merupakan neurotransmitter yang berpengaruh pada mood, pola makan, dan tidur. Kadar serotonin ditemukan menurun pada saat fase luteal atau fase pre menstrual.

Hal ini disebabkan turunnya kadar esterogen karena esterogen dapat mempengaruhi serotonin. Pada kadar level awal serotonin yang menurun maka akan terjadi gangguan tidur terutama insomnia. Gangguan tidur sangat umum terjadi pada wanita yang mengalami PMS. Gangguan tidur yang dimaksud adalah penurunan kualitas tidur pada saat fase luteal dan awal masa folikular. Gangguan tidur yang terjadi dapat berupa insomnia, hiperinsomnia dan mimpi yang mengganggu atau mimpi buruk (Lebourgeous, et.al., 2007). Wanita dengan PMS akan mengalami kesulitan untuk memulai tidur, gagal untuk bangun di waktu yang ditentukan, peningkatan adanya mimpi buruk dan secara umum mengalami penurunan tidur pada fase luteal. Efisiensi tidur pada wanita PMS sebenarnya hampir sama disetiap fasenya. Namun,kualitas tidur dapat mengalami gangguan jika wanita tersebut mengalami PMS. Semakin tinggi keparahan PMS seorang wanita, maka semakin rendah atau buruk kualitas tidurnya (Baker et. al., 2007).Tidur merupakan suatu stase aktif, penting untuk fisik mental dan emosional agar dalam kondisi yang baik dan penting pula untuk mengoptimalkan fungsi otak dan tubuh secara umum. Masalah - masalah dalam proses tidur sangat umum dan berpengaruh pada $20 \%$ remaja (Roth,2008). Survey data yang di indentifikasi terkait gangguan pada kualitas tidur, seperti sulit tidur, fatigue, letargi, dan insomnia. Namun masih sangat sedikit penelitian yang mengidentifikasikan terkait gangguan tidur pada wanita yang mengalami PMS (Baker et.al., 2007).

Aloysius S, Sukirman, \& Kamilati N. (2007) . IPA 2A Semester I Edisi Pertama. Jakarta : Yudhistira 
Anggrajani \& Muhdi. (2011). Korelasi Faktor Risiko dengan Derajat Keparahan Premenstrual Syndrome pada Dokter Perempuan. IImu Kedokteran Jiwa. FK UNAIR.

Baker, F. C., Kahan, T. L., Thinder, J., \& Colrain, I. M. (2007). Sleep Quality and The Sleep Electroencephalogram in Women with Severe Premenstrual Syndrome. Sleep in Severe Premenstrual Syndrome, 30(10), 1283 - 1291).

Firoozi, R., Kafi, M., Salehi, I., \& Shirmohammadi, M. (2012).The Relationship between Severity of Premenstrual Syndrome and Psychiatric Symtoms. Iran Journal Psychiatry, 7,36-40.

Gracia M., Wangsa B., Agung N., \& Sidharta M.V. (2011). Pengaruh Sindroma Premenstruasi Terhadap Gangguan Tidur Pada

Hidayat.A.A.(2007). Metode Penelitian Keperawatan dan Tekhnik Analisa Data. Jakarta : Salemba Medika

Ichikawa, K., Matsui, T., \& Fukazawa, S. (2008). The Relationship of Sleep Duration and Mental Health with Electrocardiographic Findings : A Retrospective Cohort Study in Okinawa, Japan. Environ Health Preventif Medication.

Indusekhar R., S.B, Usman \& S, O'Brien. (2007). Psychological Aspects of Premenstruasl Syndrome. Best Praktice and Research Clinical Obtretics and Gynaecology. Vol. 21 ,No. 2. pp. 207-220

Kanieta Y., Yokoyama E., HaranoS., TamakiT., Suzuki H., MunezawaT., Nakajima H., Asai T., \& Ohida T. (2009). Associations between Sleep Disturbance and Mental Health Status: A longitudinal Study of Japanese Junior High School Students. Sleep Medicine. Volume 10( 7), 780-786.

Kathleen, M., Lustyk, B., \&Gerrish, W. G. (2010). Premenstrual Syndrome and Premenstrual Dysphoric Disorder : Issues of Quality of Life, Stress and Exercise. Springer Science + Busines Media LLC, 1951 - 1975.
Laili \& Dewi.(2014). Tingkat Kecemasan Remaja Putri dalam Menghadapi Premenstrual Syndrome di SMP 2 Sooko Mojokerto. Jurnal.

Lebourgeous, M.E., Giannoti, F. Wolson., A.R.Hash,J.(2007). The Relationship Between Reported Sleep Hygiene In Italian And American Adolscents.. Pediatric. Vol.115 No. 1.

Mahasiswi Fakultas Kedokteran Universitas Katolik Atma jaya. Jurnal. Damianus Journal of Medicine. Fakultas Kedokteran Universitas Katolik Indonesia Atma Jaya Vol. 10 No. 2 hal 7-80.

Nasir, A., \& Muhid, A. (2011).Dasar-dasar Keperawatan Jiwa. Pengantar \& Teori .(1ed). Jakarta : Salemba Medika.

Perez-Lopez, F.R, Chendraui, P., PerezRoncero,G., Lopez-Baena, M.T., \& Cuaddros Lopez,J.L.(2009). PMS \& Premenstrual Dysphoric Disorder : Symptoms \& Cluster Influences. The Open Psychiatry Journal, 3, 47-57.

Presti \& Puspitosari. (2010). Hubungan PMS dengan Tingkat Kecemasan pada Remaja. Jurnal Universitas Muhammadiyah Yogyakarta.

Ratikasari I. (2015). Faktor - faktor yang Berhubungan dengan Sindrom Pramenstruasi Ilmu Kedokteran dan Kesehatan Masyarakat. Universitas (PMS) pada Siswi SMA 112 Jakarta Tahun 2015. Skripsi. Fakultas Negeri Syarif Hidayatullah Jakarta.

Rocha, F . E., Lima, J., Pinho, N.J., and Montarroyos,U. (2011). Essential Fatty Acids for Premenstrual Syndrome \& Their Effect on Prolactin \& Total Study. Reprod Health, 8(2).

Roth, T. (2008). Insomnia and Sleep Related Disorder. Psychiatric Annals, 38, 575 - 577.

Rusfiana A. \& Rodiani.(2016). Hubungan Premenstrual Syndrome (PMS) terhadap Faktor Psikologis pada Remaja. Jurnal Vol. 5, no.1 (19). Universitas Lampung. 
Schule, C., Northdurfer, C., \& Rupprecht R. (2014). The role of allo pregnanolone in depression and anxiety. Progress in Neurobiology. Vol. 112:79-87
Singal A. A. (2013). Tingkat Kecemasan pada Mahasiswi yang mengalami Sindrom Premenstruasi Asrama Lili. Jurnal. Universitas Advent Indonesia Bandung. 